\title{
TESTING FRESHWATER LAGO MARE DISPERSAL THEORY ON THE PHYLOGENY RELATIONSHIPS OF IBERIAN CYPRINID GENERA CHONDROSTOMA AND SQUALIUS (CYPRINIFORMES, CYPRINIDAE)
}

\author{
I. Doadrio*1 and J. A. Carmona*
}

\begin{abstract}
A phylogeny of the species in the genera Chondrostoma and Squalius was constructed based on the complete mitochondrial cytochrome $b$ gene $(1140 \mathrm{pb})$. The molecular phylogeny was used to test the effect of the Mediterranean Lago Mare dispersal theory on the processes of divergence and speciation of European freshwater fishes. Phylogenetic relationships among Squalius samples and the molecular clock revealed that the ancestor of the current Iberian Squalius species inhabited a wide geographic area in the central and southwestern part of the former Iberian Peninsula during the Miocene before the Lago Mare phase. Similarly, the four main Iberian lineages of the genus Chondrostoma originated in the Middle-Upper Miocene. Hence, the Lago Mare phase of the Mediterranean Sea seems to have been a too recent paleogeographic event to have had any major impact on the dispersion of Squalius and Chondrostoma species. However, the reduction of the water-bodies during the Tortonian and Messinian may have intensified the isolation of populations. The Operational Biogeographic Units recovered from the Squalius and Chondrostoma phylogenies also reject the Lago Mare dispersal theory and support the idea that the differentiation processes were due to both the formation of the current hydrographical basin during the Plio-Pleistocene as well as to an earlier endorrheism event that occurred prior to hydrographical configuration.
\end{abstract}

Key words: Cyprinids, Squalius, Chondrostoma, Biogeography, Mitochondrial DNA, Cytochrome $b$.

\begin{abstract}
RESUMEN
Comprobando la Teoría dispersalista del Lago Mare en las relaciones filogenéticas de los géneros ibéricos de ciprínidos Chondrostoma y Squalius (Cypriniformes, Cyprinidae)
\end{abstract}

Realizamos una filogenia de los géneros Chondrostoma y Squalius mediante el estudio de la secuencia completa del gen mitocondrial citocromo $b(1140 \mathrm{pb})$. La filogenia molecular fue usada para comprobar el efecto que la teoría de dispersión del Mediterráneo Lago Mare ha tenido sobre los procesos de divergencia y especiación en los peces de agua dulce europeos. Las relaciones filogenéticas entre las muestras de Squalius y la aplicación del reloj molecular pusieron de manifiesto que el ancestro de las actuales especies ibéricas de Squalius habitaba una amplia área del centro y suroeste de la Península Ibérica durante el Mioceno antes de la fase Lago Mare. Del mismo modo, los cuatro grandes linajes ibéricos del género Chondrostoma tuvieron su origen en el Mioceno Medio-Superior. La fase Lago Mare del Mediterráneo parece un hecho demasiado reciente como para haber tenido un impacto importante en la dispersión de las especies de los géneros Squalius y Chondrostoma. No obstante, la reducción de los cuerpos de agua durante el Tortoniense y Mesiniense pudo haber intensificado el aislamiento de las poblaciones. Las Unidades Biogeográficas Operativas obtenidas de las filogenias de los géneros Squalius y Chondrostoma también rechazan la teoría de la dispersión en la fase Lago Mare y sugieren que los procesos de 
diferenciación de la fauna de peces de agua dulce se debió al aislamiento de las cuencas hidrográficas, y a fenómenos antiguos de endorreísmo que se produjeron antes de la configuración de las cuencas hidrográficas.

Palabras Claves: Ciprínidos, Squalius, Chondrostoma, Biogeografía, ADN mitocondrial, Citocromo $b$.

Darle tiempo al recuerdo quitárselo al olvido es despertar al alma de su sueño infinito José Bergamín

\section{Introduction}

Primary freshwater fishes intolerant to marine conditions (Myers, 1938) have been of interest to biogeographers because of their dispersal ability, which is mainly restricted to freshwater contacts among different basins, lakes or rivers. It is commonly accepted that current geographical distribution of primary freshwater fishes is determined by a summary of historical changes related to the geological evolution of the region (Lundberg, 1993). Therefore, analyses of freshwater fishes allow us to test paleogeographical hypotheses, especially those related to the development of hydrographic basins and to processes of isolation and interconnection (Doadrio, 1988; Bermingham \& Martin, 1998).

Within primary freshwater fishes, cyprinids with more than 1,700 species, display a high degree of diversity. Their wide biological and ecological plasticity gives this group an important role in biogeographical theories (Zardoya \& Doadrio, 1998, 1999; Durand et al., 2003). Most theories regarding the paleobiogeography of European cyprinid fishes tried to explain which were the centre of origin and their dispersion routes (Banarescu \& Coad, 1991), and only few were interested to know the barriers that explain the vicariant patterns observed in some cyprinid fishes (Howes, 1980, 1991; Doadrio, 1990, 1994)

Banarescu's ideas, espoused in several works, have dominated European freshwater biogeography for the past 40 years (see Banarescu, 1992 and references there in). According to Banarescu (1973), current distribution of freshwater fishes in Europe resulted from a dispersal through eastern Asia into Siberia towards Central Europe and the Mediterranean countries ("the north dispersal theory"). This migratory route was only plausible when the Turgai Strait was closed 34 my ago and Europe and Asia were part of the same landmass (Briggs, 1987). The fossil record suggests a north and east Asiatic origin since the first known cyprinid fossil is from North Asia (Sytchevskaya, 1986) and until Oligocene, when the Ob Sea disappeared, no cyprinid fossils were found in Europe (Cavender, 1991).

However, it is not entirely possible to attribute the distribution of some Mediterranean taxa to northern dispersion. Because no geological evidence has been found to explain the connections between the northern and southern rivers of Italy, an alternative model (Bianco, 1990) was proposed. According to Banarescu's (1973, 1989), hypothesis Mediterranean Peninsulas were colonized via northern Europe, through river captures or through Parathetyan lakes (Economidis \& Banarescu, 1992). In contrast Bianco`s (1990) model suggests that the Mediterranean Peninsulas were colonized by crossing the Mediterranean Sea during the Messinian salinity crisis 5.3 MY; a time when the Mediterranean basin was almost completely dried up but which was subsequently refilled with fresh water from the Sarmatic Sea (Hsü at al, 1977). Bianco (1990) hypothesized that the freshwater fish fauna of the Mediterranean Peninsulas originated from a Parathethys dispersal centre.

Both theories are not entirely in conflict, however Bianco (1990) contributed to Banarescu's theory by introducing new geological advances that explained an alternative dispersal route for the endemic species from the Mediterranean area. This southern dispersal route has widespread acceptance and has now been incorporated into Banarescu's north dispersal theory (Banarescu \& Coad, 1991).

The current synthesis to explain the biogeography of European cyprinid fishes is based on two assumptions: 1) European cyprinids originated in Asia and 2) their subsequent dispersal occurred via two routes - a northern route (Banarescu's theory) and a southern route (also known as the Lago Mare theory). Central European taxa dispersed via the north while endemic freshwater fauna from the 
Mediterranean area dispersed via the southern route. The northern route probably occurred in early Miocene, while the southern route in the late Miocene. Fish dispersed through water captures (rivers or lakes) and across the Mediterranean Sea, when it was oligohalyne.

According to Popper's science demarcation dispersal theories can not be accepted because impossibility to be refuted (Croizat et al., 1974). Dispersal, in explaining everything, really explains nothing (Wiley, 1981). However, dispersal theories have experienced a comeback due to developments in scientific philosophy and molecular sciences and to evidence that Popper's criteria has serious restrictions in its application to Biological Sciences (Mayr, 1998). Molecular studies allow us to estimate information concerning the history of populations such as the spread of a taxon and the presence of migrations (Templeton et al., 1995).

In the last years, advances in molecular studies, particularly mitochondrial cytochrome $b$ and dloop genes sequences, have significantly increased our knowledge of the phylogenetic relationships of cyprinid fishes. As a result, the biogeographical hypothesis has been re-evaluated. Molecular phylogenies were used to compare current distribution patterns in order to define barriers of allopatric speciation. These barriers were dated on the basis of current geological knowledge and were then used to calibrate molecular clocks (Zardoya \& Doadrio 1999; Perdices \& Doadrio 2001; Machordom \& Doadrio 2000; Sanjur et al., 2003).

The principal vicariant model for Mediterranean freshwater fishes is based on evidence that the southern Iberian Peninsula and North Africa were part of the same land mass during almost all of the Miocene. Tectonic movement during the upper Miocene divided this land mass into two, separating and isolating populations of such genera as Barbus and Cobitis (Doadrio, 1994).

Several recent molecular studies supported the Lago Mare dispersion and have underscored the role of the Messinian salinity crisis in the speciation of cyprinid fishes (Durand et al., 2002, 2003). Lago Mare dispersal is mainly supported by the large number of polytomies found in cyprinid phylogenetic relationships. Durand et al. (2003) considered that the northern dispersal theory, in its oldest form (Banarescu, 1960), was mainly based on gradual water captures. Because they colonized gradually, the phylogenetic tree of cyprinid fishes must show bifurcations. However, the evidence of hard polytomies in the phylogenetic relationships of the genera Squalius (Durand et al., 2000) and
Chondrostoma (Durand et al., 2003) are interpreted as the split of a common ancestral population that developed through cladogenesis into multiple lineages during a short period of time. The molecular clock employed by Durand et al. (2003), which dated the hard polytomies to the Messinian period, supports the Lago Mare Dispersal Theory.

In this work we revise the phylogenetic relationships within the cyprinid genera Chondrostoma and Squalius to test the role of the Messinian period in cyprinid speciation and their dispersal through the Mediterranean Sea during the Lago Mare phase. We also investigated both the biogeographical relationships among these genera and the principal barriers that existed for cyprinids during the Cenozoic.

\section{Material and Methods}

The genus Chondrostoma comprises of approximately 30 species of freshwater fishes that are distributed throughout Europe and Asia; extending from the Iberian Peninsula to the Ural Mountains, and in the Middle East, from the Anatolian Peninsula to Iran. Our study used cytochrome $b$ sequence data belonging to 61 specimens (Table 1 , Fig. 1). The outgroups used were Rutilus rutilus, and Telestes souffia (Zardoya \& Doadrio, 1999).

The genus Squalius is also widely distributed throughout European and is highly diversified in the Mediterranean area. Recent studies separated three different lineages (Sanjur et al., 2003). A "Mediterranean lineage" is composed of small species from southern Spain, Central Italy, Southern Greece and the Balkans. A "Euro-Asiatic" lineage is principally made up of large-size taxa that is widely distributed through Central Europe, Asia and North of Mediterranean area. The third lineage, the "Paratethys lineage", contains small species around the Black Sea basin and western Anatolia. Our study used cytochrome $b$ sequence data for 47 specimens (Table 1, Fig. 1). The outgroups used were Chondrostoma willkommii and Rutilus rutilus (Zardoya \& Doadrio, 1999).

For each genus we used the complete nucleotide sequences of Cytochrome $b$ to recover the phylogenetic relationships among populations belonging to different species. Monophyletic groups of populations were employed to determine significant evolutionary units that were subsequently labelled: biogeographical units (OBU). We established phylogenetic relationships among OBUs in order to identify barriers and ancient speciation patterns. 
Table 1.- Species analysed, location data, source of DNA sequences and population number (following the Fig. 1).

\begin{tabular}{|c|c|c|c|c|}
\hline Species & River & Basin (Country) & Source & Number in the Fig. 1 \\
\hline C. arrigonis & Cabriel & Júcar (Spain) & Doadrio \& Carmona (in Press) & 59 \\
\hline C. arcasii 1 & Trabaque & Tajo (Spain) & Robalo et al. (in press) & 54 \\
\hline C. arcasii 2 & Gévalo & Tajo (Spain) & Robalo et al. (in press) & 41 \\
\hline C. arcasii 3 & Arakil & Ebro (Spain) & Robalo et al. (in press) & 47 \\
\hline C. arcasii 4 & Jalón & Ebro (Spain) & Robalo et al. (in press) & 50 \\
\hline C. arcasii 5 & Mijares & Mijares (Spain) & Robalo et al. (in press) & 55 \\
\hline C. arcasii 6 & Palancia & Palancia (Spain) & Robalo et al. (in press) & 57 \\
\hline C. arcasii 7 & Riaza & Duero (Spain) & Robalo et al. (in press) & 45 \\
\hline C. arcasii 8 & Adaja & Duero (Spain) & Robalo et al. (in press) & 44 \\
\hline C. cyri* & Araxes & Araxes (Turkey) & Durand et al. (2002) & 90 \\
\hline C. duriense 1 & Adaja & Duero (Spain) & Doadrio \& Carmona (in press) & 44 \\
\hline C. duriense 2 & Ulla & Ulla (Spain) & Doadrio \& Carmona (in press) & 1 \\
\hline C. genei 1 & Arno & Arno (Italy) & Doadrio \& Carmona (in press) & 68 \\
\hline C. genei 2 & Arno & Arno (Italy) & Doadrio \& Carmona (in press) & 68 \\
\hline C. holmwoodi & Bekincay & (Turkey) & Durand et al. (2003) & 85 \\
\hline C. lemmingii 1 & Alburrel & Tajo (Spain) & Doadrio \& Carmona (in press) & 17 \\
\hline C. lemmingii 2 & Tietar & Tajo (Spain) & Doadrio \& Carmona (in press) & 42 \\
\hline C. lemmingii 3 & Alcarrache & Guadiana (Spain) & Doadrio \& Carmona (in press) & 19 \\
\hline C. lemmingii 4 & Cigüela & Guadiana (Spain) & Doadrio \& Carmona (in press) & 39 \\
\hline C. lemmingii 5 & Belmez & Guadalquivir (Spain) & Doadrio \& Carmona (in press) & 34 \\
\hline C. lemmingii 6 & Ovejuna & Guadalquivir (Spain) & Doadrio \& Carmona (in press) & 26 \\
\hline C. lusitanicum 1 & Samarra & Samarra (Portugal) & Robalo et al. (in press) & 15 \\
\hline C. lusitanicum 2 & Colares & Colares (Portugal) & Robalo et al. (in press) & 16 \\
\hline C. macrolepidotum 1 & Paiva & Duero (Portugal) & Robalo et al. (in press) & 9 \\
\hline C. macrolepidotum 2 & Sobral & Mondego (Portugal) & Robalo et al. (in press) & 12 \\
\hline C. macrolepidotum 3 & S. Pedro & S. Pedro (Portugal) & Robalo et al. (in press) & 11 \\
\hline C. macrolepidotum 4 & Lis & Lis (Portugal) & Robalo et al. (in press) & 13 \\
\hline C. meandrense & Menderes & (Turkey) & Durand et al. (2003) & 87 \\
\hline C. miegii 1 & Jalón & Ebro (Spain) & Zardoya \& Doadrio (1998) & 50 \\
\hline C. miegii 2 & Cinca & Ebro (Spain) & Doadrio \& Carmona (in press) & 48 \\
\hline C. nasus 1 & - & Rhône (France) & Briolay et al. (1998) & 64 \\
\hline C. nasus 2 & - & Danube (Slovakia) & Durand et al. (2003) & 71 \\
\hline C. oxyrhinchum & Samur & Samur (Russia) & Zardoya \& Doadrio, 1999 & 91 \\
\hline C. polylepis 1 & Acebo & Tajo (Spain) & Doadrio \& Carmona (in press) & 7 \\
\hline C. polylepis 2 & Gallo & Tajo (Spain) & Doadrio \& Carmona (in press) & 53 \\
\hline C. prespense & Lake Prespa & Lake Prespa (Greece) & Zardoya et al. (1999) & 74 \\
\hline C. regium & - & Tigris (Turkey) & Durand et al. (2002) & 89 \\
\hline C. soetta 1 & Po & Po (Italy) & Doadrio \& Carmona (in press) & 66 \\
\hline C. soetta 2 & Po & Po (Italy) & Doadrio \& Carmona (in press) & 66 \\
\hline C. sp.al & Tea & Miño (Spain) & Doadrio \& Carmona (in press) & 2 \\
\hline C. sp. a2 & Ulla & Ulla (Spain) & Robalo et al. (in press) & 1 \\
\hline C. $s p . a 3$ & Bernesga & Duero (Spain) & Zardoya \& Doadrio (1998) & 4 \\
\hline C. sp. a4 & Tera & Duero (Spain) & Doadrio \& Carmona (in press) & 5 \\
\hline C. $s p . b 1$ & Sizandro & Sizandro (Portugal) & Robalo et al. (in press) & 14 \\
\hline C.sp. b2 & Sizandro & Sizandro (Portugal) & Robalo et al. (in press) & 14 \\
\hline C. $s p . c 1$ & Robledillo & Guadalquivir (Spain) & Zardoya \& Doadrio (1998) & 36 \\
\hline C. $s p . c 2$ & Robledillo & Guadalquivir (Spain) & Zardoya \& Doadrio (1998) & 36 \\
\hline C. $s p . d 1$ & Boina & Arade (Portugal) & Zardoya \& Doadrio (1998) & 25 \\
\hline C. $s p . d 2$ & Mira & Mira (Portugal) & Doadrio \& Carmona (in press) & 21 \\
\hline C. sp.el & Huebra & Duero (Spain) & Doadrio \& Carmona (in press) & 6 \\
\hline C. $s p . e 2$ & Turones & Duero (Spain) & Doadrio \& Carmona (in press) & 8 \\
\hline C. toxostoma & Rhône & Rhône (France) & Durand et al. (2003) & 64 \\
\hline C. toxostoma & Nive & Nive (France) & Cunha et al. (2002) & 63 \\
\hline C. turiense 1 & Mijares & Mijares (Spain) & Doadrio \& Carmona (in press) & 55 \\
\hline C. turiense 2 & Turia & Turia (Spain) & Doadrio \& Carmona (in press) & 58 \\
\hline C. vardarense 1 & Aoos & Aoos (Greece) & Zardoya et al. (1999) & 75 \\
\hline C. vardarense 2 & Aoos & Aoos (Greece) & Zardoya et al. (1999) & 75 \\
\hline C. willkommii 1 & Jandula & Guadalquivir (Spain) & Zardoya \& Doadrio (1998) & 35 \\
\hline C. willkommii 2 & Genal & Guadiaro (Spain) & Doadrio \& Carmona (in press) & 28 \\
\hline C. willkommii 3 & Gévora & Guadiana (Spain) & Doadrio \& Carmona (in press) & 18 \\
\hline C. willkommii 4 & Quejigares & Guadiana (Spain) & Doadrio \& Carmona (in press) & 37 \\
\hline Rutilus rutilus & Saone & Rhône (France) & Briolay et al. (1998) & 65 \\
\hline Telestes soufia & Saone & Rhône (France) & Briolay et al. (1998) & 65 \\
\hline Telestes beoticus & Kifissos & Kiffissos (Greece) & Zardoya \& Doadrio (1999) & 80 \\
\hline S. aradensis 1 & Cerca & Cerca (Portugal) & This paper & 22 \\
\hline$S$. aradensis 2 & Bordeira & Bordeira (Portugal) & This paper & 23 \\
\hline S. aradensis 3 & Arade & Arade (Portugal) & Sanjur et al. (2003) & 24 \\
\hline S. borysthenicus & Filiouris & Filiouris (Greece) & Zardoya et al. (1999) & 83 \\
\hline S. cabeda 1 & Po & Po (Italy) & Sanjur et al. (2003) & 66 \\
\hline S. cabeda 2 & Arno & Arno (Italy) & This paper & 68 \\
\hline
\end{tabular}


Table 1.- Especies analizadas, datos de localización de las poblaciones, fuente de donde se obtuvo las sequencias de DNA y número de población (siguiendo la Fig. 1).

\begin{tabular}{|c|c|c|c|c|}
\hline Species & River & Basin (Country) & Source & Number in the Fig. 1 \\
\hline S. cabeda 3 & Adda & Po (Italy) & This paper & 67 \\
\hline S. cabeda 4 & Tevere & Tevere (Italy) & This paper & 70 \\
\hline S. cabeda 5 & Tevere & Tevere (Italy) & This paper & 70 \\
\hline S. carolitertii 1 & Bibei & Miño (Spain) & Sanjur et al. (2003) & 3 \\
\hline S. carolitertii 2 & Hormazuela & Duero (Spain) & This paper & 46 \\
\hline S. carolitertii 3 & Mondego & Mondego (Spain) & This paper & 10 \\
\hline S. cephalus & Saone & Rhône (France) & Briolay et al. (1998) & 65 \\
\hline S. c. vardarensis & Sperchios & Sperchios (Greece) & Zardoya et al. (1999) & 82 \\
\hline S. illyricus & Cetina & Cetina (Croatia) & Durand et al. (2000) & 72 \\
\hline S. keadicus & Evrotas & Evrotas (Greece) & Zardoya et al. (1999) & 78 \\
\hline S. lepidus & Lake Beyshir & Lake Beyshir (Turkey) & Durand et al. (2000) & 88 \\
\hline S. lucumonis & Ombrone & Ombrone (Italy) & Sanjur et al. (2003) & 69 \\
\hline S. macedonicus 1 & Nestos & Nestos (Greece) & Zardoya et al. (1999) & 84 \\
\hline S. macedonicus 2 & Manikiotiko & Manikiotiko (Greece) & Zardoya et al. (1999) & 81 \\
\hline S. orientalis & Rubas & Samur (Russia) & Zardoya \& Doadrio (1999) & 91 \\
\hline S. peloponnensis 1 & Thyamis & Thyamis (Greece) & Zardoya et al. (1999) & 76 \\
\hline S. peloponnensis 2 & Alphios & Alphios (Greece) & Zardoya et al. (1999) & 77 \\
\hline S. p. moreoticus & Lake Stymphalia & Lake Stymphalia (Greece) & Zardoya et al. (1999) & 79 \\
\hline S. prespensis & Lake Prespa & Lake Prespa (Greece) & Zardoya et al. (1999) & 74 \\
\hline S. pyrenaicus 1 & Pereilas & Guadalhorce (Spain) & Doadrio \& Carmona (in press) & 32 \\
\hline S. pyrenaicus 2 & Guadalfeo & Guadalfeo (Spain) & Doadrio \& Carmona (in press) & 33 \\
\hline S. pyrenaicus 3 & Bogarda & Segura (Spain) & Sanjur et al. (2003) & 62 \\
\hline S. pyrenaicus 4 & Azuer & Guadiana (Spain) & Sanjur et al. (2003) & 38 \\
\hline S. pyrenaicus 5 & Viar & Guadalquivir (Spain) & This paper & 26 \\
\hline S. pyrenaicus 6 & Aberche & Tajo (Spain) & This paper & 43 \\
\hline S. pyrenaicus 7 & Laguna de Uña & Júcar (Spain) & Sanjur et al. (2003) & 56 \\
\hline S. pyrenaicus 8 & Matarraña & Ebro (Spain) & Sanjur et al. (2003) & 52 \\
\hline S. pyrenaicus 9 & Cimbaya & Ebro (Spain) & This paper & 51 \\
\hline S. pyrenaicus 10 & Huso & Tajo (Spain) & This paper & 40 \\
\hline S. pyrenaicus 11 & Algar & Algar (Spain) & Sanjur et al. (2003) & 61 \\
\hline S. pyrenaicus 12 & Serpis & Serpis (Spain) & Sanjur et al. (2003) & 60 \\
\hline S. pyrenaicus 13 & Sado & Sado (Spain) & This paper & 20 \\
\hline S. pyrenaicus 14 & Genal & Guadiaro (Spain) & Doadrio \& Carmona (in press) & 28 \\
\hline S. pyrenaicus 15 & Guadalmina & Guadalmina (Spain) & Doadrio \& Carmona (in press) & 31 \\
\hline S. pyrenaicus 16 & Miel & Sur (Spain) & This paper & 29 \\
\hline S. pyrenaicus 17 & Vega & Vega (Spain) & This paper & 30 \\
\hline S. smyrnaeus & Gumuldur & Gumuldur (Turkey) & Durand et al. (2000) & 86 \\
\hline S. $s p 1$ & Matarraña & Ebro (Spain) & Zardoya \& Doadrio (1998) & 52 \\
\hline S. $s p 2$ & Llobregat & Llobregat (Spain) & This paper & 49 \\
\hline S. torgalensis & Torgal & Mira (Portugal) & This paper & 21 \\
\hline S. zrmanjae & Zrmanje & Zrmanje (Croatia) & Durand et al. (2000) & 73 \\
\hline Rutilus rutilus & Saone & Rhône (France) & Briolay et al. (1998) & 65 \\
\hline
\end{tabular}

DNA was extracted from dorsal muscle and was preserved in liquid nitrogen or $70 \%$ ethanol. Voucher specimens for these species were deposited in the collections of the Museo Nacional de Ciencias Naturales, Madrid, Spain. Total cellular DNA was isolated from tissues by a standard proteinase $\mathrm{K}$ and phenol/chloroform extraction method (Sambrook et al., 1989). Frozen or 70\% ethanol preserved specimens usually gave the same quality and quantity of DNA. Two overlapping fragments of the cytochrome $b$ gene (total of $1140 \mathrm{bp}$ ) were amplified via polymerase chain reaction (PCR). The primers used for cytochrome $b$ in all species were those mentioned in Machordom \& Doadrio (2001).

The amplification process was conducted as follows: $94^{\circ} \mathrm{C}(2 \mathrm{~min}), 35$ cycles at $94^{\circ} \mathrm{C}(45 \mathrm{~s}), 48^{\circ} \mathrm{C}$ (1 $\mathrm{min}), 72^{\circ} \mathrm{C}(90 \mathrm{~s}), 72^{\circ} \mathrm{C}(5 \mathrm{~min})$. PCR mixtures were prepared in $25 \mathrm{ml}$ with a final concentration of $0.4 \mathrm{mM}$ of each primer, $0.2 \mathrm{mM}$ of each dNTP, 1.5 $\mathrm{mM} \mathrm{MgCl} 2$, and 1 unit of Taq DNA polymerase (Biotools). PCR products were checked on 1.5\% agarose gels, and cloned using the pGEM-T vector (Promega) into E. coli JM109. Positive clones were sequenced using the Big Dye Deoxy Terminator cycle-sequencing kit (Applied Biosystems Inc.). DNA sequences of both strands were obtained using M13 universal (forward and reverse) sequencing primers. All samples were sequenced on an Applied Biosystems 3700 DNA sequencer following manufacturer's instructions. Chromatograms and alignments were visually checked and verified.

In all groups, saturation was analysed by plotting the absolute number of transitions and transversions against patristic distance values (not 


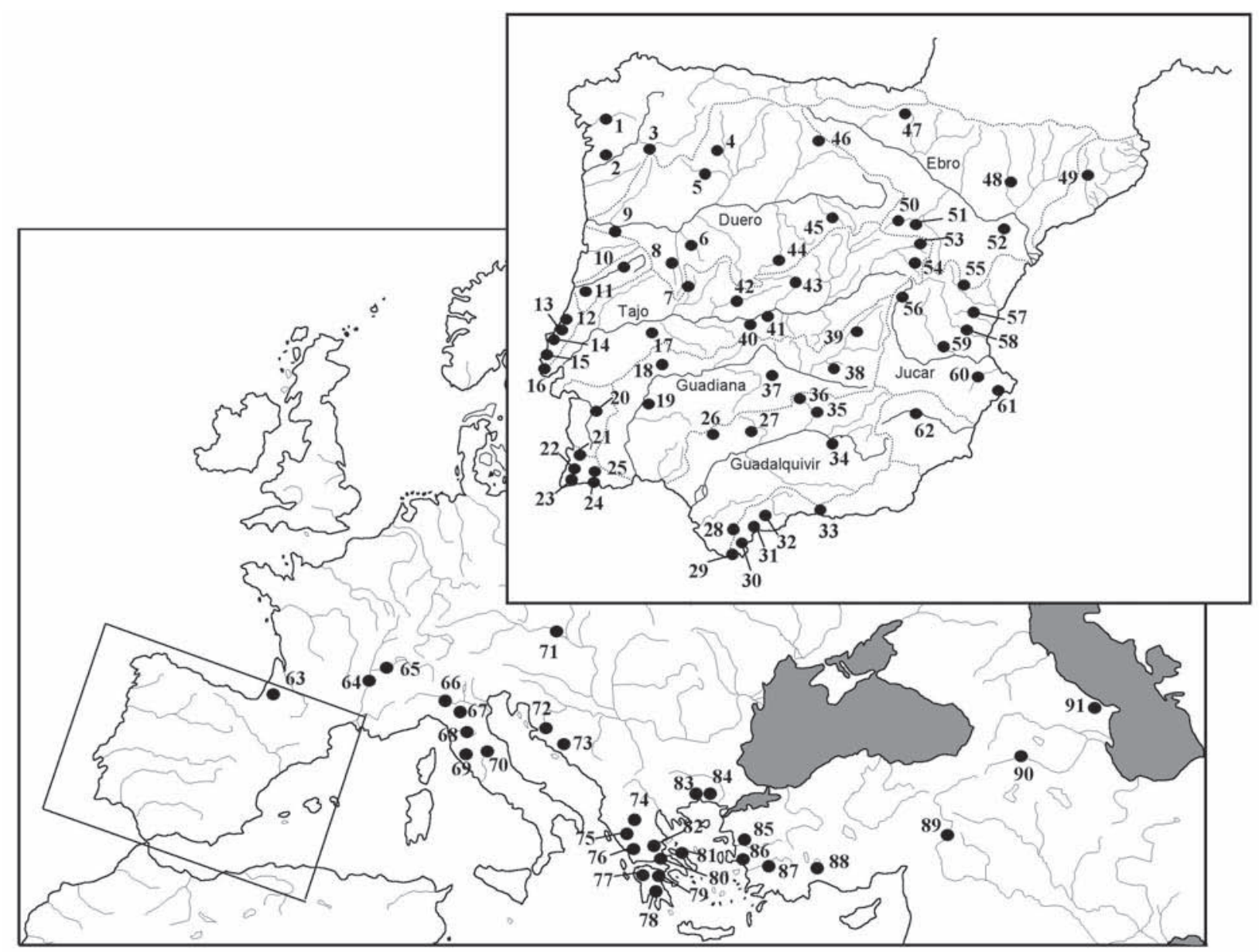

Fig. 1.- Distribution of sampling localities for Squalius and Chondrostoma specimens. Corresponding rivers and basins are described in Table 1.

Fig. 1.- Localidades de procedencia de las muestras de Squalius y Chondrostoma. En la Tabla 1 se describen los ríos y cuencas que se corresponden con estas localidades.

shown). There were not evidences of saturation at any codon position. A hierarchical likelihood ratio test (LRT) was performed to find the best model of evolution that fit our data using the program Model test 3.04 (Posada \& Crandall, 1998). Bayesian inference was performed with MrBayes 3.0 (Huelsenbeck \& Ronquist, 2001) by simulating a 1.000 .000 cycles for 4 markov chains. Burnin parameters were 300 to Squalius and 450 to Chondrostoma. To determine whether a particular tree topology corresponded to a significantly better or worse interpretation of the data than an alternative tree, we used the Shimodaira-Hasegawa test (Shimodaira \& Hasegawa, 1999), as implemented in PAUP* version $4.0 b 10$ (Swofford, 2002).
To examine whether lineages within a particular genus evolved at equal rates (molecular clock), we conducted a Likelihood Ratio Test with and without molecular clock constraints using Puzzle version 4.0.1 (Strimmer \& Von Haeseler, 1996). Since this test does not determine which lineages cause rate disparity, we also conducted a relative rates test (Sarich \& Wilson, 1973; Wu \& Li, 1985) among the main clades within a particular genus using the program RRTree $\mathrm{v} 1.1$ (RobinsonRechavi \& Huchon, 2000). We compared total number of substitutions as well as Ks (number of synonymous substitutions per synonymous site), and $\mathrm{Ka}$ (number of non-synonymous substitutions per non synonymous site). 


\section{Results}

Chondrostoma and Squalius data set included 422/418 variable sites, respectively. Third codon positions were the most informative (308/326 parsimony informative characters), followed by first codon positions ( $81 / 65$ characters).

The general time reversible model with amongsite rate heterogeneity GTRI + G + I (Yang, 1994; $\mathrm{Gu}$ et al., 1995) was selected as the best that fit the Chondrostoma and Squalius data sets. Rate matrix parameters, to Chondrostoma and Squalius respectively, were $\mathrm{R}(a)=1.7363 / 1.044, \quad \mathrm{R}(b)=$ 43.275/46.401, $\quad \mathrm{R}(c)=0.6002 / 0.5181, \quad \mathrm{R}(d)=$ $1.7236 / 1.8642, \mathrm{R}(e)=12.674 / 9.6695, \mathrm{R}(f)=1 / 1$. Base frequencies were $A=0.2666 / 0.2788, C=$ $0.2666 / 0.2964, \quad G=0.1591 / 0.1462, \quad T=$ $0.2926 / 0.2786$. Among site rate variation was approximated with the gamma distribution shape parameter $\alpha=0.54 / 1.23$. Proportion of invariable sites $I=0.27 / 0.54$. These parameters were also used for subsequent phylogenetic analyses.

The analyses of cytochrome $b$ sequence data on Squalius (47 specimens) and Chondrostoma (61 specimens) identified different mtDNA lineages within each genus. Phylogenetic analysis of the genus Squalius data set recovered the previously identified Mediterranean, Euro-Asiatic and Paratethys lineages (Sanjur et al., 2003) (Fig. 2). Phylogenetic relationships of Iberian, Greek and Italo-Balkanic species within the Mediterranean lineage were unresolved indicating that those species diverged in a brief period of time (Fig. 3).

Similarly, phylogenetic analysis of the genus Chondrostoma recovered two main lineages: Iberian and Euro-Asiatic. The two Italian species $C$. soetta and $C$. genei appeared to be independent lineages (Fig. 4). Phylogenetic relationships displayed in the bayesian tree showed two main polytomies within of the genus Chondrostoma. The first polytomy was found during the divergence process of the Italian and other Euro-Asiatic species. The second was found within the Iberian lineage and affected the four main species groups (or lineages) that inhabited the Iberian Peninsula. These groups were: Toxostoma, Lemmingii, Arcasii and Polylepis (Fig. 4).

Within the Iberian Peninsula, the recovered phylogenetic trees identified several phylogenetically significant units that we grouped geographically and called Operacional Biogeographic Units (OBU). Some of these OBUs were small because the mitochondrial lineage that defined them was present in only one or a few populations. Other
OBUs comprised more than a complete hydrographical basin and were composed of populations with closely related mitochondrial lineages belonging to widely distributed species.

\section{GENUS SQUALIUS}

The analysed Iberian Squalius species included $S$. torgalensis and $S$. aradensis, which are restricted to the extreme south-western part of Portugal, and S. carolitertii from the Mondego, Miño and Duero basins. These three species represent separate OBUs.

Populations of the fourth species, S. pyrenaicus, were widely distributed, and populations from the extreme South and from the Levantine rivers of the Mediterranean slope of Spain were the most differentiated. Among S. pyrenaicus specimens, five different OBUs were observed (Fig. 2). The first OBU included populations from the Guadiana, Guadalquivir, Segura and small independent basins from the southern part of the Iberian Peninsula. The second OBU was formed by populations from the Tajo and Júcar basins, in addition to isolated populations from the Ebro Basin. The third OBU consisted of a $S$. pyrenaicus population from the Sado Basin. The fourth OBU included populations from the Mediterranean slope (Algar and Serpis rivers). The fifth OBU was formed by small independent basins, located just near the Gibraltar strait, and were highly differentiated from the rest of $S$. pyrenaicus populations.

Squalius cephalus from Catalonia and Ebro basin belong to other different lineage and conformed a different OBU.

Using the relative-rate test (Robinson et al., 1998), we investigated whether the eight well-separated lineages, ("S. aradensis", "S. torgalensis", "S. carolitertii", "S. pyrenaicus", "Euro-Asiatic lineage", "Paratethys lineage" and "Italian and Balkanic species of the Mediterranean lineage"), had different substitution rates. Test results indicated that these clades did not exhibit significantly different evolutionary rates for synonymous and nonsynonymous substitutions with Bonferroni correction (Robinson et al., 1998).

\section{GENUS CHONDROSTOMA}

Within Chondrostoma, two independent, evolutionary lineages were found. The first lineage corresponded to Iberian and eastern France species, while the second group contained the rest of the European and Asiatic species. (Fig. 4 and 5).

Within Iberian and French species four different lineages with high support values can be distinguished. We named these groups of lineages: 


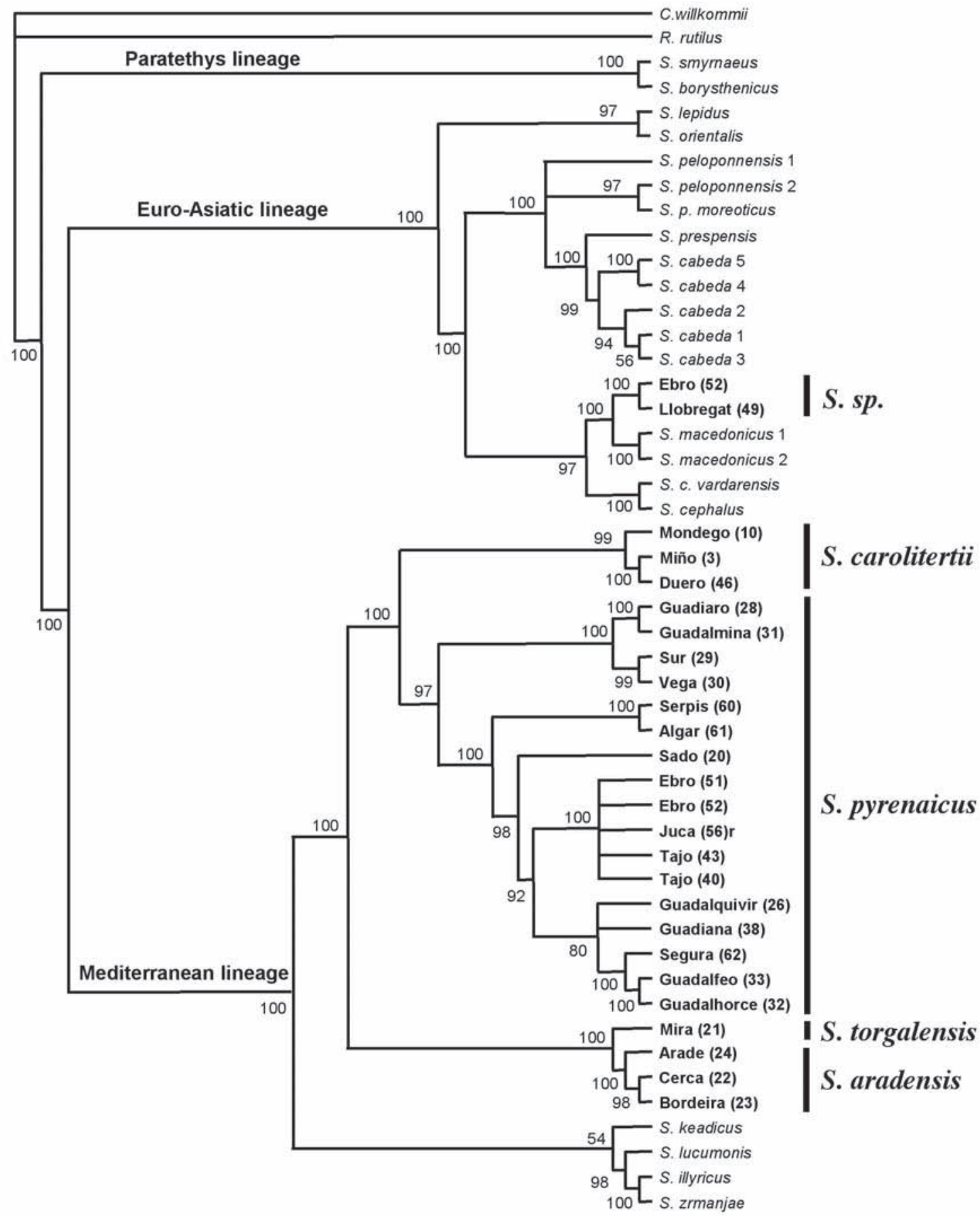

Fig. 2.- Phylogenetic relationships among Squalius populations, based on cytochrome $b$ gene sequences. Numbers above branches represent the support for Bayesian inference. Nodes with posterior probabilities values below $50 \%$ were forced to collapse and yield polytomies. Population number (in brackets) following Fig. 1 and Table 1. Different specimens of the same species were identified with numbers (without brackets) following Table1. Iberian populations in bold.

Fig. 2.- Relaciones filogenéticas entre poblaciones de Squalius, basadas en las secuencias del gen citocromo $b$. Los números en el árbol representan el soporte del análisis Bayesiano. Los nodos que muestran un soporte inferior al 50\% se colapsaron formando una politomía. Se indica los números de las poblaciones (entre paréntesis) siguendo la Fig. 1 y la Tabla 1. Los distintos ejemplares analizados de la misma especie se identificaron con números (sin paréntesis) como en la Tabla 1. Poblaciones ibéricas en negrita. 


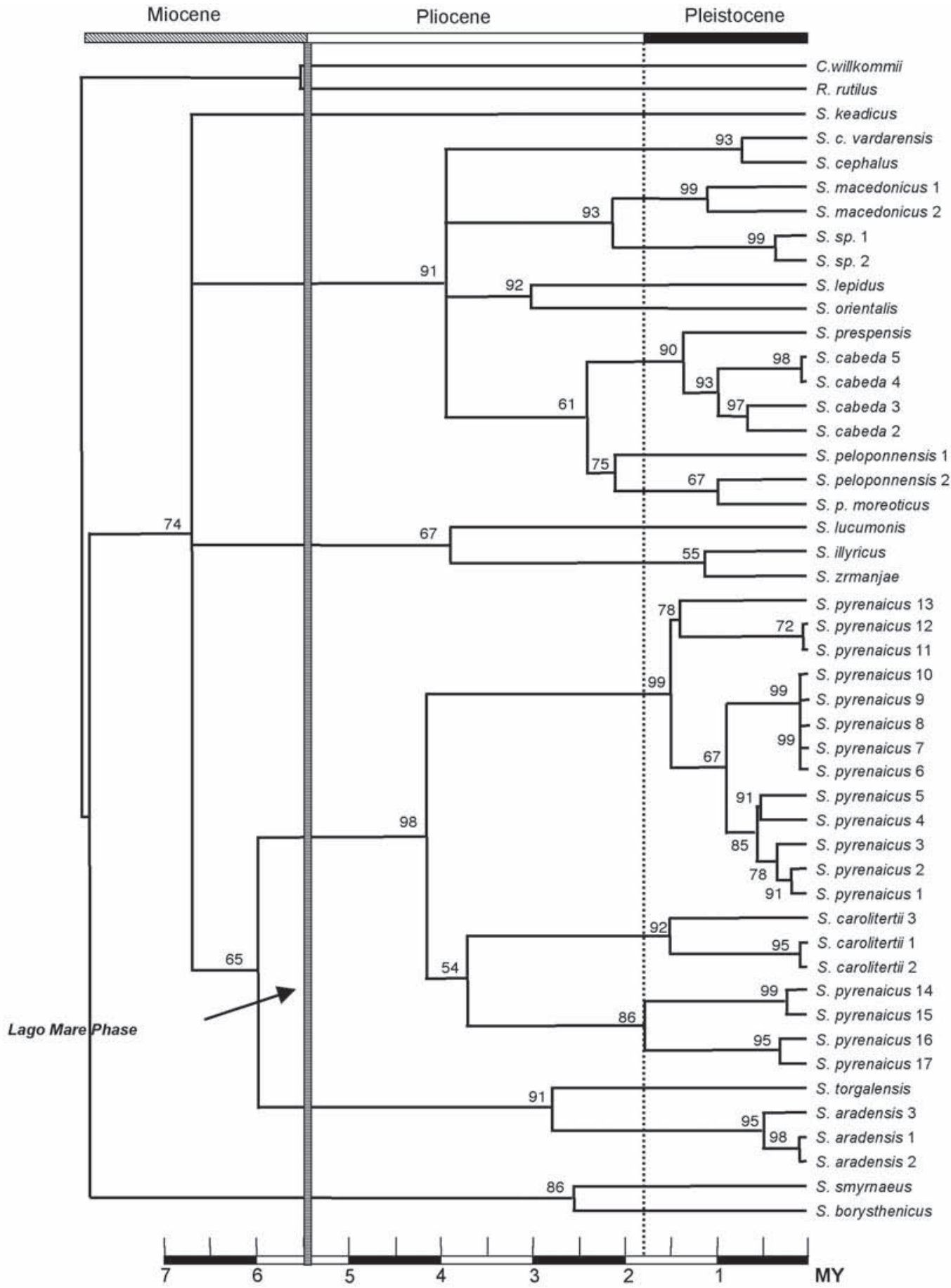

Fig. 3.- Puzzle ML tree showing the major cladogenetic events in the history of the genus Squalius. The scale bar below the tree shows the time scale resulting from the application of a molecular clock based on $1.05 \%$ divergence between taxa per MY. Numbers in nodes are support values based on 1.000,000 pseudo-replications

Fig. 3.- Árbol de máxima verosimilitud (Puzzle) que muestra los principales eventos cladogenéticos en la historia evolutiva del género Squalius. La escala bajo el árbol es una escala temporal resultante de la aplicación de un reloj molecular basado en $1.05 \%$ de divergencia entre taxones por millon de años. Los números en los nodos indican su soporte basándose en 1.000 .000 de pseudoreplicaciones 


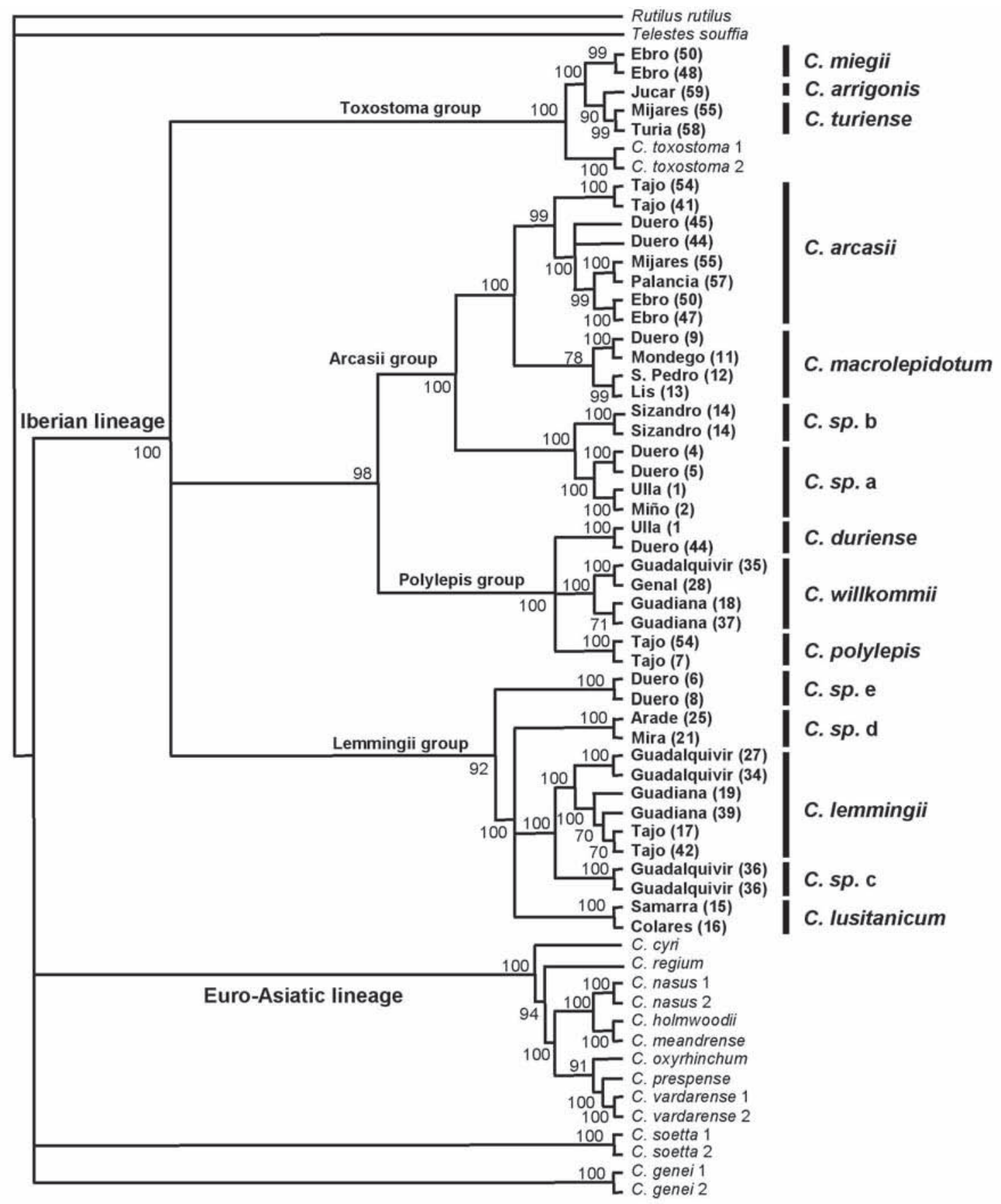

Fig. 4.- Phylogenetic relationships among Chondrostoma populations, based on cytochrome $b$ gene sequences. Numbers above branches represent the support for Bayesian inference. Nodes with posterior probabilities values below $50 \%$ were forced to collapse and yield polytomies. Population number (in brackets) following Table 1. Different specimens of the same species were identified with numbers (without brackets) following Table 1 .

Fig. 4.- Relaciones filogenéticas entre poblaciones de Chondrostoma, basadas en las secuencias del gen citocromo $b$. Los números en el árbol representan el soporte del análisis Bayesiano. Los nodos que muestran un soporte inferior al $50 \%$ se colapsaron formando una politomía. Se indica los números de las poblaciones (entre paréntesis) siguendo la Tabla 1. Los distintos ejemplares analizados de la misma especie se identificaron con números (sin paréntesis) como en la Tabla 1. 
"Arcasii", "Toxostoma", "Polylepis" and "Lemmingii". Moreover, within the Euro-Asiatic lineage the two endemic species from Italy $C$. genei and $C$. soetta conformed well separated independent lineages (Fig. 4).

In our study the Arcasii group was composed of two different clades (Fig. 4). The first clade was formed by the species $C$. arcasii and $C$. macrolepidotum. The second included two undescribed species from the western part of Iberian Peninsula. Two different OBUs were detected within $C$. arcasii. The first included the populations from the upper Tajo basin while the second OBU consisted of the populations from the upper Duero basin and the Ebro, Mijares and Palancia basins from the Mediterranean slope of Spain. Based on populations from the Portuguese Duero, Mondego Basin and other small basins from the North of Portugal, C. macrolepidotum, represents an independent OBU. Moreover, the undescribed species $C$. sp. a was composed of populations grouped into two OBUs: the Galician Rivers (Ulla and Miño) and the northwestern part of the Duero basin. The population from the Sizandro basin, which belonged to $C . s p$. $b$, was considered as a separate OBU.

The Polylepis group comprised three species: $C$. duriense, $C$. polylepis and $C$. willkomii. Relationships among these species were unresolved. C. duriense populations from the Duero and Galician Basins represent one OBU, while $C$. polylepis from the Tajo, Mondego, Sorraia and Sado Basins defined another OBU. Populations of C. willkommii from the Guadiana River, which constituted one independent OBU, were sister groups of other populations from southern Spain that represented a different OBU.

The Toxostoma group included four species that formed four respective OBUs: $C$. arrigonis endemic to Júcar River in Spain, C. turiense endemic to the Turia and Mijares Rivers in Spain, C. miegii endemic to northeastern Spain and $C$. toxostoma endemic to France. $C$. arrigonis and $C$. turiense were sister group taxa to $C$. toxostoma.

Finally, the Lemmingii group was comprised of at least five species. Three of them corresponded to populations of an undescribed species, which formed three respective OBUs: the Robledillo River in the Guadalquivir basin $(C . s p . c)$, the Mira and Arade Basins in Portugal (C. $s p . d$ ) and the southwestern Spanish Duero (C. sp. e). The Sado Basin and lower Tajo Basin from Portugal defined the $\mathrm{OBU}$ for $C$. lusitanicum populations. Finally, we distinguished two OBUs among $C$. lemmingii populations. The first corresponded to the Guadalquivir Basin and the second to the Guadiana and Tajo Basins.

Using the relative-rate test (Robinson et al., 1998), we investigated whether the seven clades ("Arcasii", "Toxostoma", "Polylepis", "Lemmingii", "Euro-Asiatic", C. genei and C. soetta, which had well-separated lineages, had different substitution rates. The results of the test indicated that these clades did not exhibit significantly different evolutionary rates for synonymous and non-synonymous substitutions with Bonferroni correction (Robinson et al., 1998).

\section{Discussion}

Different authors have calibrated a molecular clock for Cyprinidae using fossil or geological data. Zardoya \& Doadrio (1999) calibrate a molecular clock in $0.73 \%$ divergence per lineage per million years using the opening of the Gibraltar strait 5.3 million years ago and the formation of the Corinthus strait in Greece. Posteriorly, on the basis of this geological event Machordom \& Doadrio (2001) estimated a molecular clock of $1.3 \%$ of divergence per pairwaise comparison per million years $(0.65$ per lineage per million years). These molecular clocks were highly congruent with the estimate of $1.05 \%$ divergence per million years (0.53 per lineage per million years) calculate by Dowling et al. (2002) with fossil data. We used this latter molecular clock to estimate both divergence dates as well as principal events that caused speciation in Squalius and Chondrostoma. Durand et al. (2003) used the same molecular clock to date the divergence time of the genus Chondrostoma.

\section{GENUS SQUALIUS}

Regarding the origins of the Iberian Squalius species, our results showed that they do not constitute a monophyletic group. Two different lineages were detected in the Iberian Peninsula, suggesting that the colonization of this area was not a single event, but probably the result of at least two invasions. One of the two lineages, corresponding to the Northeastern Iberian population of Squalius, is phylogenetically much closer to the Northern Greek and Central Europe populations of $S$. cephalus than it is to any other species on the Iberian Peninsula. Species of the second lineage found within the Iberian Peninsula, $S$. pyrenaicus, $S$. carolitertii, $S$. aradensis and $S$. torgalensis, form a monophyletic group with eight well-recognised OBUs. 


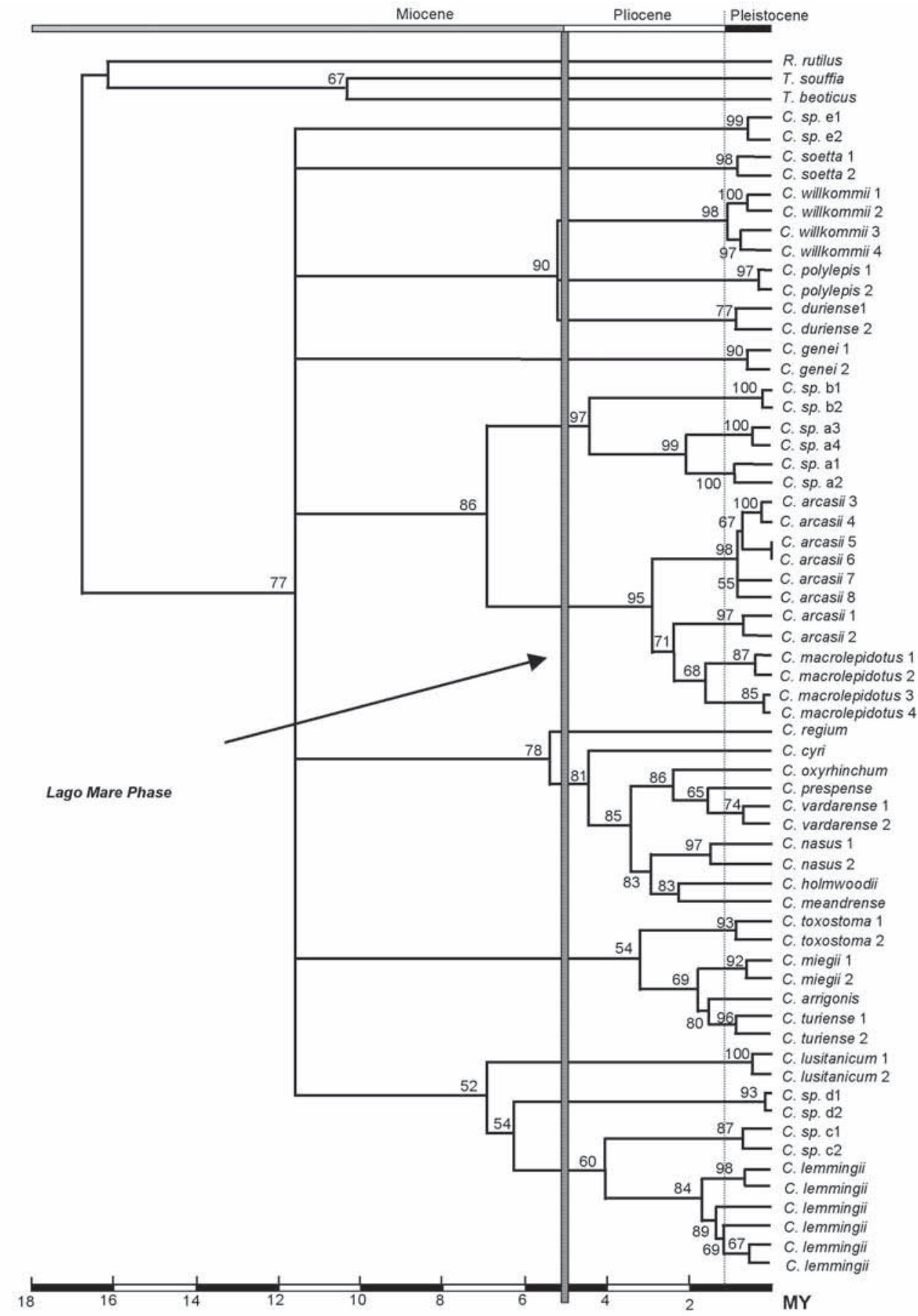

Fig. 5.- Puzzle ML tree showing the major cladogenetic events in the history of the genus Chondrostoma. The scale bar below the tree shows the time scale resulted from the application of a molecular clock based on $1.05 \%$ divergence between taxa per MY. Numbers in nodes are support values based on $1.000,000$ pseudo-replications

Fig. 5.- Árbol de máxima verosimilitud (Puzzle) que muestra los principales eventos cladogenéticos en la historia evolutiva del género Chondrostoma. La escala bajo el árbol es una escala temporal resultante de la aplicación de un reloj molecular basado en $1.05 \%$ de divergencia entre taxones por millon de años. Los números en los nodos indican su soporte basándose en 1.000 .000 de pseudoreplicaciones 
Squalius aradensis and $S$. torgalensis were grouped together and appeared basal to $S$. pyrenaicus and $S$. carolitertii indicating an early differentiation of this biogeographical area, probably during the Messinian period (6 MYA). In this period, it is likely that many basins almost dried up, isolating the southwestern part of the Iberian Peninsula. This result supports previous studies based on allozymes and partial cytochrome $b$ sequences (Coelho et al., 1995; Brito et al., 1997).

The speciation process that gave rise to $S$. $c a$ rolitertii can be attributed to the earlier formation of the Duero Basin, which was an endorrheic lagoon in the Miocene period (López-Martínez, 1989; De la Peña, 1995). The rest of the Iberian rivers were configured during Plio-Pleistocene and almost all of them have been isolated from one another since this time (Fig. 3).

Among $S$. pyrenaicus populations from the extreme South of Spain were clustered in a separate and basal group, and showed higher genetic divergence than the remaining populations of $S$. pyrenaicus (Fig. 2). Interestingly, the Levantine populations (Serpis and Algar basins) also displayed high genetic differentiation, which suggests that these populations are not connected to the remaining populations of $S$. pyrenaicus.

Populations from the Tajo basin are phylogenetically close to those from the Júcar and Ebro. The affinities between Tajo and Júcar basins must be interpreted as an historical event of interconnection since their headstreams are located very close to each other. Similarly, C. arcasii populations in the Tajo, Júcar, Ebro and Levantine Basins represent a single OBU. In addition, the inclusion in this OBU of $S$. pyrenaicus populations from the Matarraña and Cimbaya Rivers from the Ebro Basin is rather interesting since a similar pattern has been reported for Cobitis paludica, which inhabits the Tajo Basin and is simpatric with C. calderoni in the Ebro basin (Doadrio et al., 1991).

The phylogeny of Iberian Squalius species detected two different monophyletic lineages, colonized at two different times on the Iberian Peninsula: the Meridional group and the Central Europe group. The level of species diversity found in the Central Europe lineage, together with their phylogenetic relationships and the geographic distribution of their OBUs, suggest that this lineage colonized the Iberian Peninsula after the Meridional group.

The molecular clock confirms that the ancestor of the Mediterranean group seems to have inhabited a wide geographic area in the central and south- western part of the former Iberian Peninsula during the Miocene before the Lago Mare phase. Hence, the Lago Mare phase of the Mediterranean Sea seems to have been a recent paleogeographic event to have had any major impact on species dispersion of the genus Squalius. The effect of the lacustre Lago Mare phase may have been limited to local dispersal events. However, the reduction of the water-bodies during the Tortonian and Messinian may have intensified the isolation of populations (Doadrio, 2001).

\section{GENUS CHONDROSTOMA}

Cytochrome $b$ sequence data did not clearly resolve the phylogenetic relationships among the four Iberian lineages.

The main Chondrostoma lineages were differentiated in the Middle-Upper Miocene (Fig. 5). Unlike most of Europe which was experiencing a dry period during this time, the Iberian Peninsula was wet, a condition which facilitated the formation of the main endorreic lagoons on the Peninsula. This period would coincide with the alleged origin of the genus Squalius (Sanjur et al., 2003). However, the highest diversification of the family would have occurred during the Pliocene. This high diversification during the Pliocene agrees with previous works (Banarescu, 1989; Zardoya \& Doadrio, 1999).

Regarding the distribution pattern of the four Iberian lineages, two significant features must be pointed out. First, Polylepis and Toxostoma lineages showed OBUs that, respectively, comprised complete hydrographical basins whereas Arcasii and Lemmingii lineages showed more complex geographical structures and were represented by several OBUs that consisted only of portions of current hydrographical basins (Fig. 6). Such differential distribution patterns are supposedly related to reproductive migrations developed by Polylepis and Toxostoma lineages, which include large-sized species. On the contrary, reproductive migrations are not present in species belonging to Arcasii and Lemmingii lineages, which include species of small size.

Secondly, it is worth noting that Polylepis and Toxostoma lineages are allopatric, as are the Arcasii and Lemmingii lineages (Fig. 6).

The differentiation of species belonging to the Polylepis lineage, distributed throughout the Atlantic slope of Iberian Peninsula, can be explained by the configuration of three main OBUs separated by the Central Cordillera and Toledo Mountains. The molecular clock employed here indicated that the diver- 

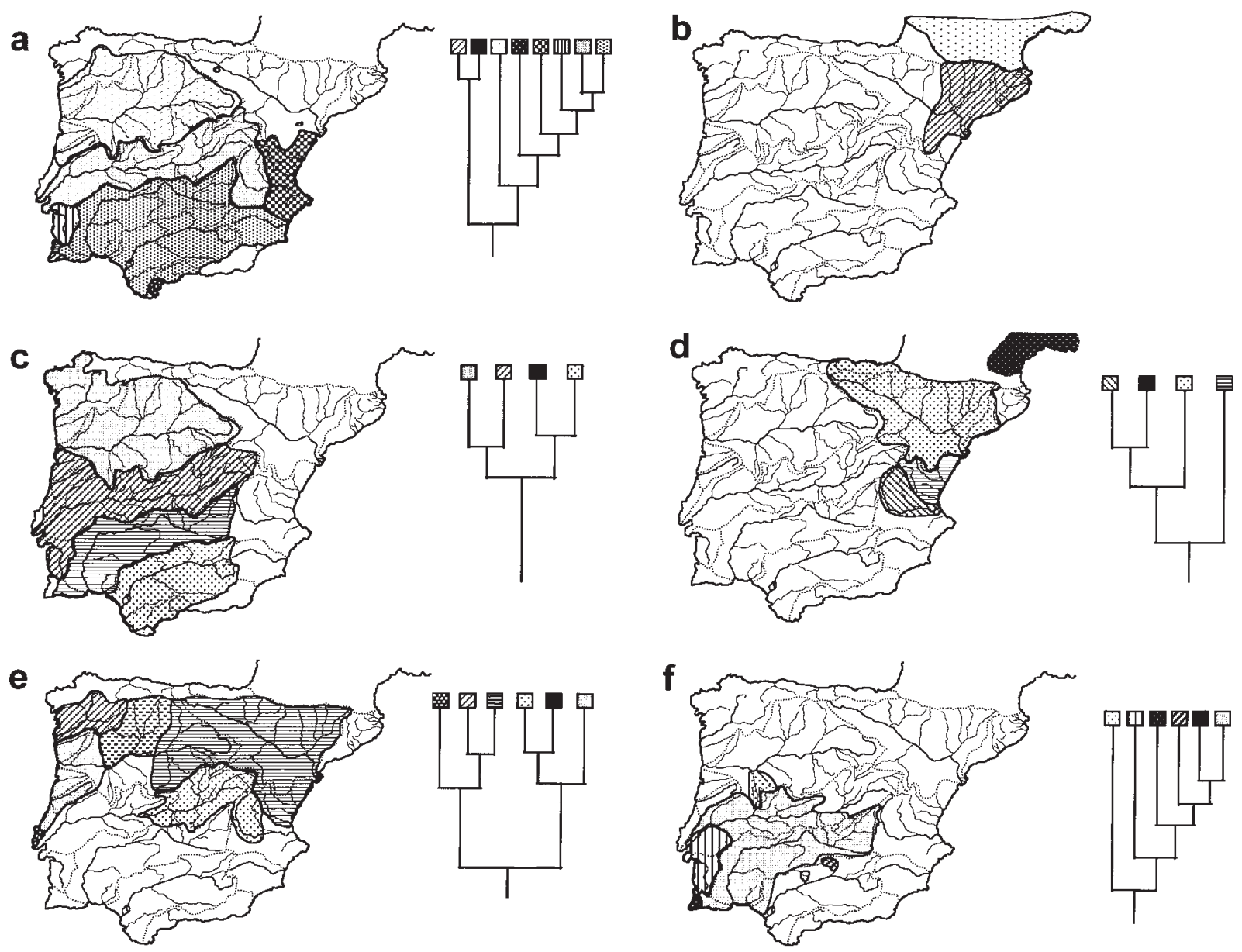

Fig. 6.- Main OBUs and their phylogenetic relationships for Iberian species of Squalius (a-b) and Chondrostoma (c-f): a.- Iberian Squalius species of the Mediterranean lineage, b.- Iberian Squalius species of the Euro-Asiatic lineage, c.- Polylepis group, d.Toxostoma group, e.- Arcasii group and f.- Lemmingii group.

Fig. 6.- Principales OBUs y sus relaciones filogenéticas obtenidos para las especies Ibéricas de Squalius (a-b) y Chondrostoma (c-f): a.- especies Ibéricas de Squalius pertenecientes al linaje Mediterráneo, b.- especies Ibéricas de Squalius pertenecientes al linaje Euroasiático, c.- grupo Polylepis, d.- grupo Toxostoma, e.- grupo Arcasii y f.- grupo Lemmingii.

gence among $C$. duriense, $C$. polylepis and $C$. willkommii took place during the Messinian, which coincided with the Mediterranean transgression.

The Toxostoma lineage species diverged later, about 3 MY, in the Pliocene. No geological data are available to explain the connection between the Iberian basins and the Rhône basin during the Pliocene. This connexion between the Rhône and the Ebro Rivers could only have been possible during the Messinian 5.3-7 MYA when the Rhône discharged into the Mediterranean basin.
Within the Arcasii and Lemingii lineages the speciation process took place in the Miocene, about 7.5 MY, during the Tortonian. Consequently, the geographical structure created by their OBUs is more complex and reflects the influence of the earlier endorrheism. During this period the early Duero and Ebro endorrheic lagoons were still connected, as were the upper Tajo and Júcar basins.

The ancient endorrheism seems to be highly related with cladogenesis within the Iberian Chondrostoma clade. 
THE LAGO MARE PHASE AND THE WESTERN PART OF THE MEDiterRANEAN AREA

The four main lineages of the genus Chondrostoma that inhabited the Iberian Peninsula originated before the Messinian salinity crisis (Fig. 5). Our result, reject an extensively colononized the Iberian Peninsula through a freshwater Mediterranean Lake, as has been proposed for other freshwater fishes (Bianco, 1990). Penzo et al. (1998) and Zardoya \& Doadrio (1999) considered unrealistic this extensive dispersion in gobiids and cyprinids. However, a general dispersion model has been proposed for the genus Chondrostoma during the Lago Mare Phase (Durand et al., 2003).

No geological arguments exist to support that the Lago Mare phase affected the western part of the Mediterranean area. The presence in the upper evaporates of a non-evaporitic subdivision was interpreted by Hsü et al. (1978) as a Lago Mare phase. However, the fact that the seismic register of Upper Evaporites in West-Mediterranean (Montandert et al., 1978) recognized an average interval velocity of $3.5 \mathrm{Km} / \mathrm{s}$, similar to the overlying Pliocene sediments, could be the result of lesser freshwater input in the western Mediterranean area than in eastern areas (Griffin, 2002). Important changes in the salinity seem that particularly affected the Cyrenaica Lake in the eastern Mediterranean area but not the western Mediterranean basin. Paleontological evidence also does not support the theory that cyprinids in the Iberian Peninsula originated during the Messinian crisis because of the presence of cyprinid fossils, including, the genus Squalius, in Iberian deposits, since UpperOligocene (De la Peña, 1995).

Molecular phylogenies that find a basal polytomy among different genera have been the principal argument used to support dispersion through an extensive freshwater lake. The polytomy found in the work of Durand et al. (2000) on the genus Squalius was resolved by Sanjur et al. (2003) just by increasing the number of taxa analyzed.

Bianco's (1990) dispersal theory that freshwater fishes originated in Paratethyan Sea was recently modified by Durand et al. (2003) after introducing new geological evidence. Durand et al. (2003) considered that freshwater fishes scattered through out the margins of the Paratethys Sea during the short time that the Mediterranean Sea was fresh water. It is predicted that colonization and speciation occurred quickly and in a short period of time displaying a model of hard polytomies in the molecular phylogenetic trees. We have found no support for this model with our analyse on the genera Squalius or Chondrostoma because the polytomies in our trees are found before the Lago Mare phase. The differences dating the politomies between Durand et al. (2003) and our own results could be due to the sampling. The radiation showed before the Lago Mare phase could be an artefact as consequence of the type of molecular marker used (Cytochrome b). Other molecular markers should be used to verify if the radiation shown really existed.

Dispersion due to river captures could have been possible during the Messinan because the drawdown of Mediterranean sea caused the headwaters of the main European and African rivers to become incised into the bedrock during the Mediterranean regression. Moreover, because of wet periods and the monsoon influence (Griffin. 2002), dispersion of freshwater fish fauna by sea was possible in the southeastern area of the Mediterranean. In the western Mediterranean basin the situation was probably different. The Iberian Peninsula had a dry climate during the Messinian, causing the endorrheic lakes to shrink in size and probably fragment. Hence, the principal effect of the dry Messinian period in the Iberian Peninsula would have been the isolation and differentiation of populations. This would have then been followed by speciation in allopatry rather than a quick radiation after a dispersal event.

Finally, the serious differences in the distribution pattern displayed by Squalius and Chondrostoma species do not support a dispersal scenario like that proposed by the Lago Mare hypothesis. Because both the dry as well as the wet periods during the Cenozoic lasted for long periods of time, the dispersion and speciation of freshwater fishes in the Mediterranean region was more gradual than the Lago mare hypothesis predicts.

\section{ACKNOWLEDGEMENTS}

The authors thank V. Almada, P. Garzón, G. GonzálezCarmona, F. Lerma, A. Machordom, A. Perdices, J. Robalo and C. Santos for fish collection. L. Alcaraz assisted in the DNA sequencing. The senior author of this paper was lucky to share dreams and interests about research in the Museo Nacional de Ciencias Naturales with Fermín Martín Piera for around twenty years. J. A. Carmona was supported by a postdoctoral grant of the CAM. This research was supported in part by the projects. REM2001-0662/G10 and CAM project Ref. 07M/0109/02.

\section{References}

BANARESCU, P., 1960. Einige Fragen zur Herkunt und verbreitung der süsswasserfichfauna der europäich- 
mediterranen Unterregion. Archiv für Hydrobiologie, 57(1/2): 15-134.

BANARESCU, P., 1973. Origin and affinities of the freshwater fish fauna of Europe. Ichthyologia, 5(1): 1-8.

BANARESCU, P., 1992. Zoogeography of freshwaters: distribution and dispersal of freshwaters animals in North America and Eurasia Vol. 2 Aula-Verlag, Wiesbaden. 1617 pp.

BANARESCU, P., 1989. Zoogeography and history of the freshwater fish faune of Europe. In: J. Holcik (ed). The freshwater fishes of Europe, Vol 1. AULAVerlag. Wiesbaden: 80-107.

Banarescu, P. \& CoAD, B. W., 1991. Cyprinids of Eurasia. In: I. J. Winfield \& J. S. Nelson (eds.). Cyprinid fishes, systematics, biology and exploitation. Chapman \& Hall. London: 127-155.

Bermingham, E., McCafferty, S. \& Martin, A., 1997. Fish biogeography and molecular clocks: perspectives from the Panamanian Isthmus. In: T. Kocher \& C. Stepien (eds.). Molecular Systematics of Fishes. Academic Press. New York: 113-126.

Bermingham, E. \& Martin, A. P., 1998. Comparative mtDNA phylogeography of neotropical freshwater fishes: testing shared history to infer the evolutionary landscape of lower Central America. Molecular Ecology, 7: 499-517.

Bianco, P. G, 1990. Potential role of the palaeohistory of the Mediterranean and Paratethis basins on the early dispersal of Euro-Mediterranean freshwater fishes. Ichthyological Exploration of Freshwaters, 1: 167-184.

Briggs, J. C., 1987. Biogeography and Plate Tectonics. Elsevier Science. New York. 216 pp.

Brito, R. M., Briolay, J., Galtier, N., Bouvet, Y. \& Coelho, M. M., 1997. Phylogenetic relationships within genus Leuciscus (Pisces, Cyprinidae) in Portuguese freshwaters, based on mitochondrial DNA cytochrome $b$ sequences. Molecular Phylogenetics and Evolution, 8: 435-442.

Carmona, J. A., Domínguez, J. \& Dohdrio, I., 2000. Congruence between allozyme and cytocrome $b$ gene sequence data in assessing genetic differentiation within the Iberian endemic Chondrostoma lemmingii (Pisces: Cyprinidae). Heredity, 84: 721-732.

Cavender, T. M., 1991. The fossil record of the Cyprinidae. In: I. J. Winfield \& J. S. Nelson (eds.). Cyprinid fishes, systematics, biology and exploitation. Chapman \& Hall. London: 1-33.

Coelho, M. M., Brito, R. M., Pacheco, T. R., Figueiredo, D. \& Pires, A. M., 1995. Genetic variation and divergence of Leuciscus pyrenaicus and $L$. carolitertii (Pisces, Cyprinidae). Journal of Fish Biology, 47: 243-258.

Croizat, L., Nelson, G. \& Rosen D. E., 1974. Centers of Origin and Related Concepts. Systematic Zoology, 23: $265-287$.
De La PeÑA, A., 1995. Tertiary fishes from the Iberian Continental Basins: History and fossil record. Coloquios de Paleontología, 47: 25-47.

DoAdrio, I., 1988. Delimitation of areas in the Iberian Peninsula on the basis of the freshwater fishes. Bonner Zoologische Beiträge, 39: 113-128.

DoAdrio, I., 1990. Phylogenetic relationships and classification of west Paleartic species of the genus Barbus (Osteichthyes, Cyprinidae) Aquatic Living Resources, 3: 265-282.

DOADRIO, I., 1994. Freshwater fish fauna of North Africa and its biogeography. Kontinlijk Museum voor Midden-Africa Tervuren Belgie Annalen Zoologische Wetenschappen, 275: 21-34.

DOADRIO, I., 2001. Origen y evolución de la ictiofauna continental española. In: I. Doadrio (ed.). Atlas y Libro Rojo de los Peces Españoles. DGCONACSIC. Madrid: 20-34.

DoAdrio, I. \& CARMONA, J. A. (In press). Phylogenetic relationships of the genus Chondrostoma using cytochrome b sequences. Molecular Phylogenetics and Evolution.

DoAdrio, I., Elvira, B. \& Bernat, Y., 1991. Peces continentales españoles. Inventario y clasificación de zonas fluviales. Colección Técnica, ICONA. Madrid. 221 pp.

Dowling, T. E., Tibbets, C. A., Minckley, W. L. \& Sмith, G. R., 2002. Evolutionary relationships of the plagopterins (Teleostei: Cyprinidae) from cytochrome $b$ sequences. Copeia, 2002(3): 655-678.

Durand, J. D., Bianco, P. G., Laroche, J. \& Gilles, A., 2003. Insight into the origin of endemic Mediterranean ichthyofauna - Phylogeography of Chondrostoma genus (Teleostean, Cyprinidae). Journal of Heredity, 94(4): 315-328.

Durand, J. D., Tsigenopoulos, C. S., Unlü, E. \& Berrebi, P., 2002. Phylogeny and biogeography of the family Cyprinidae in the Middle East inferred from cytochrome $b$ DNA - Evolutionary significance of this region. Molecular Phylogenetics and Evolution, 22: 91-100.

Durand, J. D., Ünlü, E., DoAdrio, I., Pipoyan, S. \& Templeton, A. R., 2000. Origin, radiation, dispersion and allopatric hybridization in the chub, Leuciscus cephalus. Proceedings of the Royal Society of London B, 267: 1687-1697.

ECONOMIDIS, P. S. \& BANARESCU, P., 1991. The distribution and origin of freshwater fishes in the Balkan Peninsula, especially in Greece. Internationale Revue der gesamten Hydrobiologie, 76: 257-283.

Gu, X., Fu, Y. X. \& LI, W. H., 1995. Maximum likelihood estimation of the heterogeneity of substitution rate among nucleotide sites. Molecular Biology and Evolution, 12: 546-557.

GRIFFIN, D. L. 2002 Aridity and humidity: two aspects of the late Miocene climate of North Africa and the 
Mediterranean. Palaeogeography, Palaeoclimatology, Palaeoecology, 182(1-2): 65-91.

HowES, G. J., 1991. Systematics and biogeography: an overview. In: I. J. Winfield \& J. S. Nelson (eds.). Cyprinid fishes, systematics, biology and exploitation. Chapman \& Hall. London: 1-33.

Hsü, K., Montadert, L., Bernuilli, D., Cita, M. B., ERICKSON, A., GARRISON, R. E., KidD, R. B., MÈLIERÉS, F., Müller, C. \& Wright, R. 1977. History of the Mediterranean salinity crisis. Nature, 267: 399-403.

Huelsenbeck, J. P. \& Ronquist, F., 2001. MRBAYES: Bayesian inference of phylogenetic trees. Bioinformatics, 17(8): 754-755.

LóPEZ-MARTínEZ, N., 1989. Tendencias en paleobiogeografía. El futuro de la biogeografía del pasado. In: E. Aguirre (ed.). Paleontología. CSIC. Madrid: 271-299.

LundBERG, J. G., 1993. African-South American freshwater fish clades and continental drift, problems with a paradigm. In: P. Goldblatt (ed.). Biotic Relationships between Africa and Sout America. Yale University Press. New Haven: 156-198

MACHORDOM, A. \& DoAdrio, I., 2001. Evidence of a Cenozoic Betic-Kabilian connection based on freshwater fish phylogeography (Luciobarbus, Cyprinidae). Molecular Phylogenetics and Evolution, 18: 252-263.

MAYr, E., 1998 This is Biology. The Science of the living world. The Belknap Press of Harvard University Press. Cambridge. 323 pp

Montandert, L., Letouzey, J. \& Mauffret, A., 1978 Messinian event: seismic evidence. In: K. J. Hsü, L. Montandert et al. Init. Rep. DSDP, 42(1): 1037-1050.

Myers, G. S., 1938. Freshwater fishes and West Indian zoogeography. Annual Report, Smithsonian Institution, 1937: 339-364.

Penzo, E., Gandolfi, G., Bargelloni, L., Colombo, L. \& Patarnello, T., 1998. Messinian salinity crisis and the origin of freshwater lifestyle in western Mediterranean gobies. Molecular Biology and Evolution, 15(11):1472-80.

Perdices, A. \& DoAdrio, I., 2001. The molecular systematics and biogeography of the European cobitids based on mitochondrial DNA sequences. Molecular Phylogenetics and Evolution, 19(3): 468-478.

PosadA, D. \& CRANDALl, K.A., 1998. MODELTEST: testing the model of DNA substitution. Bioinformatics, 14(9): 817-818.

Robalo, J., Santos, C., Almada, V. \& Doadrio, I., (In press). Phylogeography of two iberian endemic cyprinids fishes (Chondrostoma arcasii-Chondrostoma macrolepidotus) inferred from sequence data. Molecular Phylogenetics and Evolution.

Robinson-Rechavi, M. \& Huchon, D., 2000. RRTree: Relative-Rate Tests on a tree. Bioinfomatics, 16: 296-297.
SAnjur, O., CARMOnA, J. A. \& DoAdrio, I., 2003. Molecular phylogeny of Iberian Chub (genus Squalius, Cyprinidae), inferred from molecular data. Molecular Phylogenetics and Evolution, 29(1): 20-30.

SAmbrooK, J., Fritsch, E. F. \& Maniatis, T., 1989. Molecular Cloning: A Laboratory Manual. Cold Spring Harbor Laboratory. New York.

SARICH, V. M. \& Wilson, A. C., 1973. Generation time and genomic evolution in primates. Science, 179: 1144-1147.

Shimodaira, H. \& Hasegawa, M., 1999. Multiple comparisons of Log-likelihoods with applications to phylogenetic inference. Molecular Biology and Evolution, 16:1114-1116.

Strimmer, K. \& Von Haeseler, A., 1996. Quartet puzzling: a quartet maximum-likelihood method for reconstructing tree topologies. Molecular Biology and Evolution, 13: 964-969.

SytchevskayA, E. K., 1986. Palaeogene freshwater fish fauna of the USSR and Mongolia. The Joint SovietMongolia Paleontological Expedition (Transactions), 29: 1-157.

Swofford, D. L., 2002. PAUP. Phylogenetic Analysis Using Parsimony (*and Other Methods". Sinauer Associates. Sunderland.

Templeton, A. R., Routman, E. \& Phillips, C., 1995. Separating population structure from population history: a cladistic ananlysis of the geographical distribution of mitochondrial DNA haplotypes in the Tiger Salamander, Ambystoma tigrinum. Genetics, 140: 767-782.

Wiley, E. O., 1981. Phylogenetics: The theory and practice of phylogenetic systematics. John Wiley \& Sons. New York. 439 pp.

WU, C. I. \& LI, W. H., 1985. Evidence for higher rates of nucleotide substitution in rodents than in man. Proceeding of the National Academy of Sciences of the United States of America, 82: 1741-1745.

YANG, Z., 1994. Maximum Likelihood Phylogenetic Estimation from DNA Sequences with Variable Rates over Sites: Approximate Methods. Molecular Biology and Evolution 39:306-314

ZARDOYA, R. \& DOADRIO, I., 1998. Phylogenetic relationships of Iberian cyprinids: systematic and biogeographical implications. Proceedings of the Royal Society of London B, 265: 1365-1372.

ZARDOYA, R. \& DOADRIO, I., 1999. Molecular evidence on the evolutionary and biogeographical patterns of European cyprinids. Journal of Molecular Evolution, 49: 227-237. 